\title{
A METHOD FOR THE DETERMINATION OF THE $\mathrm{pH}$ OF 0.05-MOLAL SOLUTIONS OF ACID POTASSIUM PHTHAL- ATE WITH OR WITHOUT POTASSIUM CHLORIDE
}

\author{
By Walter J. Hamer and S. F. Acree
}

\section{ABSTRACT}

The $\mathrm{pH}$ values of a $0.05-\mathrm{m}$ solution of acid potassium phthalate containing various amounts of potassium chloride were determined at 5 -degree intervals from $0^{\circ}$ to $60^{\circ} \mathrm{C}$, inclusive, from the measurements of the electromotive force of galvanic cells without liquid junction using hydrogen and silver-silver-chloride electrodes. A method is described for the determination of the $\mathrm{pH}$ directly from the emf by means of the equation

$$
\mathrm{pH}=\left[\left(E-E^{\circ}\right) /(R T / F)+\log m_{\mathrm{C} 1}-P\right] / Q,
$$

where $P$ and $Q$ are constants whose numerical values depend on the ionic strength of the solution and the nature of the cation and $E^{\circ}, R, T$, and $F$ have their usual significance. By this method a $0.05-m$ solution of acid potassium phthalate, National Bureau of Standards Standard Sample 84a, is found to have a pH of 4.008 at $25^{\circ} \mathrm{C}$, and this value does not vary much with the temperature. A description is also given of the application of the method to the determination of the $\mathrm{pH}$ and the ionic strength of unknown solutions of low salt content.

Equations were formulated to express the variation of the $\mathrm{pH}$ of a $0.05-m$ solution of acid potassium phthalate with temperature and with the concentration of potassium chloride. The $\mathrm{pH}$ values may be computed for temperatures from $0^{\circ}$ to $60^{\circ} \mathrm{C}$, inclusive, by the equation

$$
\mathrm{pH}=5.13 \log T+1519.62 / T+0.01092 T-17.039,
$$

where $T=t^{\circ} \mathrm{C}+273.16$. The $\mathrm{pH}$ values for concentrations of potassium chloride from 0 to $0.05 \mathrm{~m}$ may be computed by the equation

$$
\mathrm{pH}_{\text {with salt }}=\mathrm{pH}_{\text {without salt }}-0.993 m_{\mathrm{KCl}}+2.124 m_{\mathrm{KCl}}^{2} \text {. }
$$

The solutions may be readily prepared from known weights of acid potassium phthalate, potassium chloride, and distilled water and are well suited for use as $\mathrm{pH}$ standards, in that their $\mathrm{pH}$ values do not change much with temperature or dilution.

\section{CONTENTS}

I. Introduction

II. Experimental procedure _.

III. Method for the determination of the $\mathrm{pH}$ of acid potassium phthalate $\ldots 218$

IV. References_...

\section{INTRODUCTION}

Buffer solutions prepared with acid potassium phthalate are extensively used for the calibration of commercial $\mathrm{pH}$ meters and other $\mathrm{pH}$ equipment. A $0.05-m$ solution is generally employed and 
conveniently prepared from the dry salt and distilled water. The $\mathrm{pH}$ value of this solution has usually been determined from the measurements of galvanic cells comprised of various types of hydrogen and calomel electrodes. By this method, $\mathrm{pH}$ values ranging from 3.92 to 4.01 [1 to 4$]^{1}$ have been reported for a temperature of $25^{\circ} \mathrm{C}$. The differences in these $\mathrm{pH}$ values are due partly to lack of equilibrium of the galvanic cell $[5,6,7]$, partly to liquid-junction errors [8 to 12] arising from the use of calomel electrodes, and partly to the use of hydrogen-ion concentration rather than hydrogen-ion activity as the basis of the definition of the $\mathrm{pH}$ scale. ${ }^{2}$ This paper gives a method for the determination of the $\mathrm{pH}$ of a $0.05-m$ solution of acid potassium phthalate from the measurements of the emf of galvanic cells without liquid junction. The effect of varying amounts of potassium chloride upon the $\mathrm{pH}$ of a $0.05-m$ solution of acid potassium phthalate is also given. The latter data are included because they give information concerning the activity coefficients of the ions composing the mixture. ${ }^{3}$ A description is also given of the application of the method to the determination of the $\mathrm{pH}$ values and ionic strengths of unknown solutions of low salt content [24].

\section{EXPERIMENTAL PROCEDURE}

The method is based upon the measurements of the emf of the galvanic cell

$$
\mathrm{Pd}, \mathrm{H}_{2}(\mathrm{~g})|\mathrm{KHPh}(0.05 \mathrm{~m}), \mathrm{KCl}(m)| \mathrm{AgCl}(\mathrm{s}) \mid \mathrm{Ag}(\mathrm{s})
$$

for a series of concentrations $(m)$ of potassium chloride, in which $\mathrm{KHPh}$ designates acid potassium phthalate, and the other symbols have their usual significance.

The hydrogen electrodes used were made of platinum foil (10 by 15 by $0.2 \mathrm{~mm}$ ), and were plated with a thin coat of palladium sponge by electrolysis of a 1-percent solution of palladium chloride containing a trace of lead acetate for 1 minute at a current density of 0.04 $\mathrm{amp} / \mathrm{cm}^{2}$ [5]. Electrodes of this type do not catalyze the reduction of acid potassium phthalate and function reversibly for well over 100 hours in solutions containing various amounts of potassium chloride. Silver-silver-chloride electrodes of the thermal-electrolytic type were prepared from pure materials, as described in a previous paper [13]. They were sufficiently aged to bring them to a stable state. Other equipment, including the cells, thermostat, and emf-recording instruments have been described in detail [13].

The acid potassium phthalate used was National Bureau of Standards Standard Sample 84a, having a certified purity of 100.00 percent,

\footnotetext{
1 Figures in brackets indicate the literature references at the end of this paper.

2 It is well known that an exact differentiation between hydrogen-ion concentration and acti vity cannot be made, since the value of the activity coefficient of the hydrogen-ion cannot be determined without some assumption. Hitchcock and Taylor [3], and MacInnes, Belcher, and Shedlovsky [4] in their methods obtain a quantity which approximates the value of the hydrogen-ion activity. In the work on pH standards in this Bureau the assumption is made that the activity coefficient of the hydrogen-ion is equal to the mean activity coefficient of hydrochloric acid, a quantity which can be determined experimentally from electromotiveforce measurements. See references [8,13 to 15] for discussions of this assumption in connection with work on $\mathrm{pH}$ standards.

If the dissociation of an acid salt conformed to the simple law of mass action for finite concentrations, the effect of a neutral salt on the dissociation of the acid salt could be determined solely from its concentration. However, as a result of ionic association, the nature of the medium, and salt effects, certain processes occur which lead to departures from ideality. For a review of the earlier studies of the effects of salts on the dissociation and reactions of weak electrolytes, see the paper by Burton, Hamer, and Acree [16]. See also the papers by Loomis and Acree [17] and Bronsted [18].
} 
determined by titration. It was prepared for use according to the directions given in the Bureau certificate. Potassium chloride was recrystallized twice from conductivity water and then thrice by the addition of 95-percent ethanol to remove the last traces of bromide. It was dried for at least 10 hours at $110^{\circ} \mathrm{C}$ and allowed to cool in a desiccator, using concentrated sulfuric acid as the desiccant. The solutions were prepared from known weights of the dry salts and conductivity water. The concentrations were expressed in terms of weight of solute per $1,000 \mathrm{~g}$ of water. All the solutions were deaerated by means of purified hydrogen gas before they were introduced into the cells. Corrections were made for the loss of water from the solutions during the deaeration process and for the differences between the densities of hydrogen and air. The specific conductance of the water used in this work was generally $1.0 \times 10^{-6}$ mho and sometimes was as low as $0.6 \times 10^{-6}$ mho.

In table 1 , the values of emf given were corrected in the usual manner to 1 atmosphere of hydrogen pressure. The results of triplicate (three) determinations (values) are given for $25^{\circ} \mathrm{C}$ and of duplicate determinations (two) for $45^{\circ} \mathrm{C}$. The values of the emf were first recorded at $25^{\circ} \mathrm{C}$. The bath was then cooled to $0^{\circ} \mathrm{C}$ in 5-degree steps and the emf recorded at each temperature. Then the temperature of the bath was raised to $25^{\circ} \mathrm{C}$ and the emf again recorded. The temperature of the bath was then raised to $60^{\circ} \mathrm{C}$ in 5-degree steps and the emf recorded at each temperature. Finally, the bath was cooled first to $45^{\circ} \mathrm{C}$ and then to $25^{\circ} \mathrm{C}$ and the emf measured at each temperature. The first and final emf at $25^{\circ} \mathrm{C}$ agreed within $0.09 \mathrm{mv}$, or $0.002 \mathrm{pH}$ unit, on the average for the nine concentrations.

TABLE 1.-Electromotive forces of the galvanic cell $\mathrm{Pd}, \mathrm{H}_{2}(\mathrm{~g}) \mid \mathrm{KHPh}(0.05 \mathrm{~m})$, $\mathrm{KCl}(\mathrm{m})|\mathrm{AgCl}(\mathrm{s})| \mathrm{Ag}(\mathrm{s})$ from $0^{\circ}$ to $60^{\circ} \mathrm{C}$

[Hydrogen electrodes were aged for 1 hour; silver-silver-chloride electrodes were aged for 12 hours.]

\begin{tabular}{|c|c|c|c|c|c|c|c|c|c|}
\hline \multirow{2}{*}{$\begin{array}{l}\text { Tempera- } \\
\text { ture }\end{array}$} & \multicolumn{9}{|c|}{ Molality of potassium chloride $=m$} \\
\hline & 0.05 & 0.03 & 0.02 & 0.01 & 0.007 & 0.005 & 0.003 & 0.002 & 0.001 \\
\hline 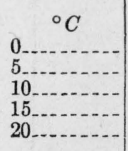 & $\begin{array}{c}v \\
0.52725 \\
.52976 \\
.53229 \\
.53482 \\
.53738\end{array}$ & $\begin{array}{c}v \\
0.53976 \\
.54255 \\
.54532 \\
.54806 \\
.55085\end{array}$ & $\begin{array}{c}v \\
0.54962 \\
.55261 \\
.55550 \\
.55847 \\
.56143\end{array}$ & $\begin{array}{c}v \\
0.56611 \\
.56936 \\
.57263 \\
.57583 \\
.57915\end{array}$ & $\begin{array}{c}v \\
0.57459 \\
.57803 \\
.58144 \\
.58485 \\
.58828\end{array}$ & $\begin{array}{c}v \\
0.58255 \\
.58620 \\
.58963 \\
.59322 \\
.59678\end{array}$ & $\begin{array}{c}v \\
0.59476 \\
.59849 \\
.60222 \\
.60591 \\
.60968\end{array}$ & $\begin{array}{c}v \\
0.60420 \\
.60812 \\
.61210 \\
.61602 \\
.61994\end{array}$ & $\begin{array}{c}v \\
0.62059 \\
.62478 \\
.62908 \\
.63334 \\
.63760\end{array}$ \\
\hline $\begin{array}{l}25 \mathrm{a} \\
25 \mathrm{~b} \\
25 \mathrm{c}^{\circ}- \\
30 \\
35 \\
35\end{array}$ & $\begin{array}{r}.53999 \\
.53998 \\
.54003 \\
.54250 \\
.54510\end{array}$ & $\begin{array}{l}.55363 \\
.55364 \\
.55369 \\
.55644 \\
.55919\end{array}$ & $\begin{array}{l}.56440 \\
.56435 \\
.56438 \\
.56738 \\
.57023\end{array}$ & $\begin{array}{l}.58255 \\
.58257 \\
.58270 \\
.58566 \\
.58888\end{array}$ & $\begin{array}{l}.59173 \\
.59174 \\
.59184 \\
.59514 \\
.59854\end{array}$ & $\begin{array}{l}.60040 \\
.60042 \\
.60045 \\
.60394 \\
.60748\end{array}$ & $\begin{array}{l}.61354 \\
.61356 \\
.61368 \\
.61731 \\
.62107\end{array}$ & $\begin{array}{l}.62396 \\
.62393 \\
.62403 \\
.62789 \\
.63187\end{array}$ & $\begin{array}{l}.64186 \\
.64190 \\
.64201 \\
.64618 \\
.65036\end{array}$ \\
\hline $\begin{array}{l}40 \\
45 \mathrm{~d}^{-} \\
45 \\
50 \\
55 \\
60 \\
60\end{array}$ & $\begin{array}{l}.54752 \\
.55008 \\
.55011 \\
.55264 \\
.55519 \\
.55773\end{array}$ & $\begin{array}{l}.56190 \\
.56452 \\
.56455 \\
.56746 \\
.57023 \\
.57287\end{array}$ & $\begin{array}{l}.57318 \\
.57600 \\
.57606 \\
.57908 \\
.58207 \\
.58487\end{array}$ & $\begin{array}{l}.59206 \\
.59528 \\
.59529 \\
.59859 \\
.60184 \\
.60506\end{array}$ & $\begin{array}{l}.60187 \\
.60514 \\
.60519 \\
.60871 \\
.61210 \\
.61543\end{array}$ & $\begin{array}{l}.61096 \\
.61443 \\
.61454 \\
.61810 \\
.62164 \\
.62508\end{array}$ & $\begin{array}{l}.62475 \\
.62847 \\
.62853 \\
.63234 \\
.63610 \\
.63974\end{array}$ & $\begin{array}{l}.63571 \\
.63963 \\
.63972 \\
.64366 \\
.64767 \\
.65152\end{array}$ & $\begin{array}{l}.65457 \\
.65866 \\
.65875 \\
.66304 \\
.66729 \\
.67137\end{array}$ \\
\hline
\end{tabular}

a emf recorded 6 hours aiter the start of flow of the hydrogen gas.

b emf recorded after measurements at $0^{\circ}, 5^{\circ}, 10^{\circ}, 15^{\circ}, 20^{\circ}$, and $25^{\circ}$ (first) C.

- emf recorded after measurements at all the other temperatures were made.

$\mathrm{d}$ emf recorded after measurements at the lower temperatures were made.

e emf recorded after measurements were made at $50^{\circ}, 55^{\circ}$, and $60^{\circ} \mathrm{C}$. 


\section{METHOD FOR THE DETERMINATION OF THE pH OF ACID POTASSIUM PHTHALATE}

The relation between the emf of the cell and the hydrogen- and chloride-ion activities of the solution is given by the equation

$$
E=E^{\circ}-\left(R T / F^{\prime}\right) \ln \left(a_{\mathrm{H}} a_{\mathrm{Cl}}\right)=E^{\circ}-\left(R T / F^{\prime}\right) \ln \left(f_{\mathrm{H}} f_{\mathrm{C} 1} m_{\mathrm{H}} m_{\mathrm{Cl}}\right),
$$

where $E$ is the measured emf; $E^{\circ}$ the potential of the silver-silverchloride electrode at unit activity of hydrochloric acid; $a, f$, and $m$ are, respectively, the activity, activity coefficient, and molality of the ionic species denoted by subscripts; and $R, T$, and $F$ have their usual

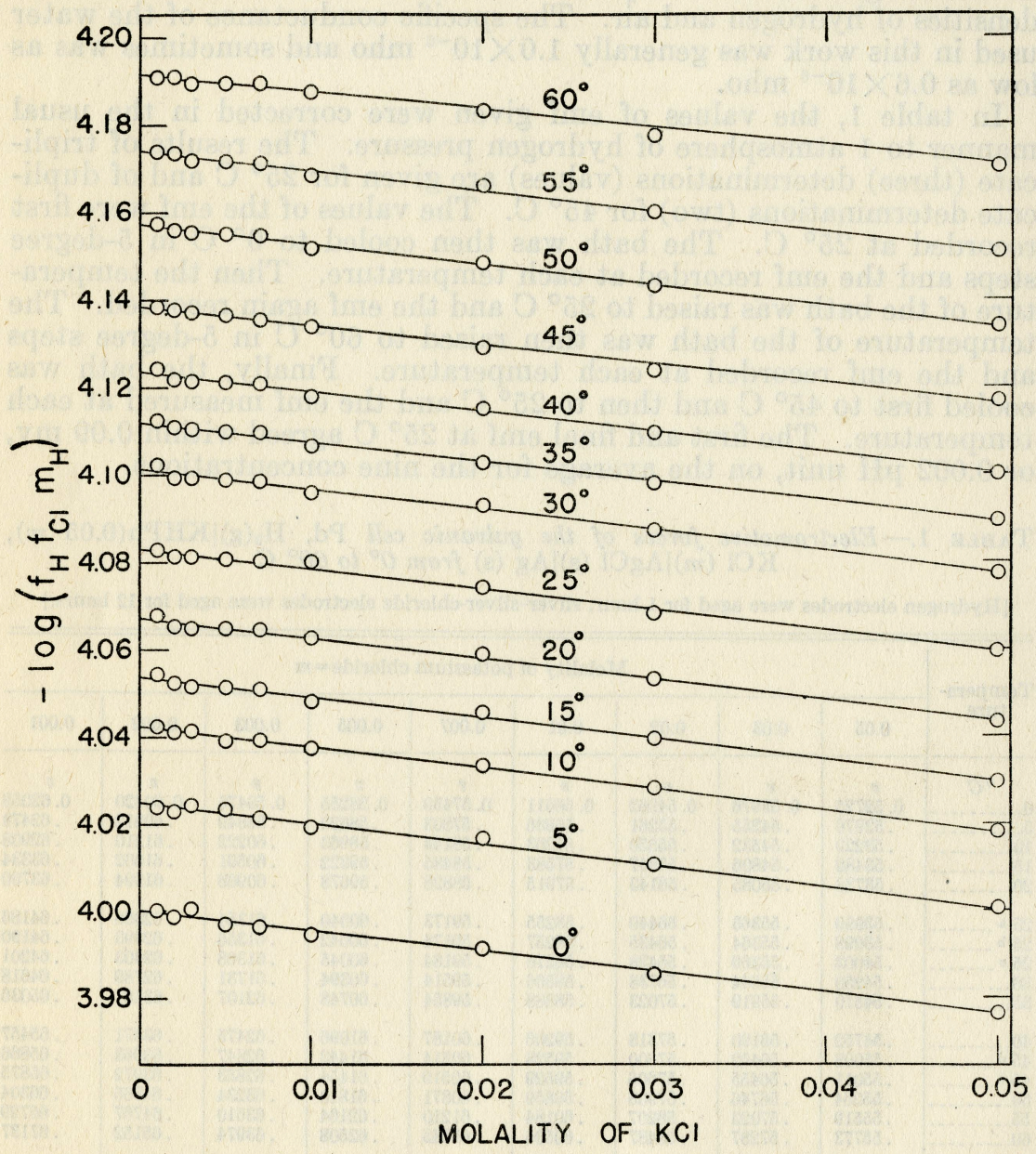

- Figure 1.-Plots of the numerical values of - $\log \left(f_{\mathrm{H}} f_{\mathrm{Cl}} m_{\mathrm{H}}\right)$ at $0^{\circ}$ to $60^{\circ} \mathrm{C}$ for solutions of $0.05-m$ acid potassium phthalate containing different amounts of potassium chloride.

$0.09,0.06,0.04,0.03,0.02$, and 0.01 were subtracted from the values at $0^{\circ}, 5^{\circ}, 10^{\circ}, 15^{\circ}, 20^{\circ}$, and $25^{\circ} \mathrm{C}$ for convenience in plotting. 
significance. Upon collection of all known quantities on the left, eq 1 becomes

$$
\left(E-E^{\circ}\right) /\left(R T / F^{\prime}\right)+\log m_{\mathrm{Cl}}=-\log \left(f_{\mathrm{H}} f_{\mathrm{Cl}} m_{\mathrm{H}}\right),
$$

by which values of $-\log \left(f_{\mathrm{H}} f_{\mathrm{Cl}} m_{\mathrm{H}}\right)$, a quantity proportional to $\mathrm{pH}$ or $-\log \left(f_{\mathrm{H}} m_{\mathrm{H}}\right)$, may be calculated. It would therefore be a simple matter to calculate $\mathrm{pH}$ values from the emf if values of $-\log f_{\mathrm{Cl}}$ for the solution were known. Hamer and Acree [13] have shown how values of $-\log f_{\mathrm{CI}}$ may be determined from the emf of cells without liquid junction, using the equations of Debye and Hückel. This method entails comprehensive studies, however, of the thermodynamics of the system under study, in this case of various mixtures of $o$-phthalic acid and potassium hydroxide. However, a simpler method, although probably less precise, may be followed and is herein described for the temperature $25^{\circ} \mathrm{C}$.

From the emf determinations recorded in table 1, values of-log $\left(f_{\mathrm{H}} f_{\mathrm{C} 1} m_{\mathrm{H}}\right)$ were calculated by eq 2 for each concentration of potassium chloride for the different temperatures, using the data for $E^{\circ}$ determined by Harned and Ehlers [19] and values of $R, T$, and $F$ employed by Hamer, Burton, and Acree [14], and are given in table 2. These values are then plotted against the molality of potassium chloride, as shown in figure 1, and extrapolation made to zero salt concentration, which gives the value of $-\log \left(f_{\mathrm{H}} f_{\mathrm{Cl}} m_{\mathrm{H}}\right)^{\circ}$ for $0.05-m$ acid potassium phthalate in the absence of chloride ion. The superscript, zero, is used to denote quantities for solutions containing no chloride ion. Within the experimental error (0.002 in $\mathrm{pH}$ unit), the values vary linearly with the molality of potassium chloride. This variation may be expressed by

$$
-\log \left(f_{\mathrm{H}} f_{\mathrm{Cl}} m_{\mathrm{H}}\right)=-\log \left(f_{\mathrm{H}} f_{\mathrm{Cl}} m_{\mathrm{H}}\right)^{\circ}-k m_{\mathrm{KCl}},
$$

where $k$ is a constant whose magnitude is given by the slope of the straight lines of figure 1 . Values of $-\log \left(f_{\mathrm{H}} f_{\mathrm{Cl}} m_{\mathrm{H}}\right)^{\circ}$ and $k$ for the different temperatures were determined by the method of least squares and are given in the last two columns of table 2 . At $25^{\circ}$. C, $-\log \left(f_{\mathrm{H}} f_{\mathrm{Cl}} m_{\mathrm{H}}\right)^{\circ}$ equals 4.0934 .

TABLE 2.-Numerical values of - $\log \left(f_{\mathrm{H}} f_{\mathrm{C} 1} m_{\mathrm{H}}\right)$ in 0.05- $m$ acid potassium phthalate

\begin{tabular}{|c|c|c|c|c|c|c|c|c|c|c|c|}
\hline \multirow{2}{*}{$\begin{array}{l}\text { Tempera- } \\
\text { ture }\end{array}$} & \multicolumn{11}{|c|}{ Molality of potassium chloride } \\
\hline & 0.05 & 0.03 & 0.02 & 0.01 & 0.007 & 0.005 & 0.003 & 0.002 & 0.001 & 0.000 & $k^{b}$ \\
\hline${ }^{\circ} \mathrm{C}$ & & & & & & & & & & & \\
\hline & $\begin{array}{l}4.0665 \\
4.0606\end{array}$ & $\begin{array}{l}4.0755 \\
\text { 4. } 0706\end{array}$ & $\begin{array}{l}\text { 4. } 0814 \\
\text { 4. } 0768\end{array}$ & $\begin{array}{l}4.0847 \\
4.0794\end{array}$ & $\begin{array}{l}4.0865 \\
4.0816\end{array}$ & $\begin{array}{l}4.0871 \\
4.0836\end{array}$ & & & & $\begin{array}{l}\text { 4. } 0903 \\
\text { 4. } 0851\end{array}$ & $\begin{array}{r}0.48 \\
.48\end{array}$ \\
\hline & 4. 0581 & 4. 0683 & 4. 0735 & 4. 0 & 4.0 & $\begin{array}{l}4.0 \\
4.0\end{array}$ & $\begin{array}{l}4.08 \\
4.08\end{array}$ & $\begin{array}{l}4.0 \\
4.0\end{array}$ & 4.0 & $\begin{array}{l}\text { 4. } 0801 \\
4.0826\end{array}$ & $\begin{array}{r}.40 \\
49\end{array}$ \\
\hline & 4. 0596 & 4. 0695 & 4. 0756 & 4. 0782 & 4. 0811 & 4.08 & 4.0817 & 4. 0825 & 4. 0845 & 4. 0840 & .48 \\
\hline & 4. 0633 & 4. 0731 & 4. 0790 & 4. 0827 & 4. 08 & 4.08 & 4.0850 & 4.08 & 4. 0880 & 4. 0875 & .48 \\
\hline & 4. 0695 & 4. 0783 & 4. 08 & 4.09 & 4. 0 & 4. 0 & 4.0913 & 4. 0915 & 4. 0 & 4. 0 & .48 \\
\hline & 4. 0772 & 4. 0872 & 4. 09 & 4. 0 & 4. 0 & 4. 0 & 4. 0994 & 4. 09 & 4.1 & & .48 \\
\hline & 4. 0894 & 4. 0980 & 4. 1026 & 4. 1067 & 4. 1098 & 4. 11 & 4. 1105 & 4. 1110 & 4.1125 & 4. 1122 & .46 \\
\hline & 4. 0999 & 4. 1095 & 4. 1151 & 4.1180 & 4.1210 & 4. 1213 & 4. 1215 & 4.1219 & 4. 1245 & 4. 1237 & .47 \\
\hline & 4. 1167 & 4. 1238 & 4. 1291 & 4. 1340 & 4. 1355 & 4. 1366 & 4. 1372 & 4. 1 & & & .45 \\
\hline & 4. 1338 & 4. 1432 & 4. 1485 & 4. 1518 & 4. 1548 & 4. 1552 & 4.15 & 4.1560 & 4.1575 & 4. 1574 & .47 \\
\hline & 4.1508 & 4.1600 & 4. 1659 & 4.1685 & 4. 1712 & 4. 1717 & 4. 1720 & 4. 1736 & 4. 1740 & 4.1741 & .46 \\
\hline & 4. 1702 & 4. 1775 & 4. 1830 & 4.1875 & 4.1895 & 4.1895 & 4. 1895 & 4. 1916 & 4. 1910 & 4. 1917 & .44 \\
\hline
\end{tabular}
containing various amounts of potassium chloride from $0^{\circ}$ to $60^{\circ} \mathrm{C}$

a Only the first recorded emf were used at these temperatures. Data obtained with the second or third measurements of the emf agree with the above data within 0.0009 on the average. $b k$ is the coefficient in the equation $-\log \left(f_{\mathrm{H}} f_{\mathrm{Cl}} m_{\mathrm{H}}\right)=-\log \left(f_{\mathrm{H}} f_{\mathrm{Cl}} m_{\mathrm{H}}\right)^{\circ}-k m_{\mathrm{ECl}}$ where $-\log \left(f_{\mathrm{H}} f_{\mathrm{C} 1} m_{\mathrm{H}}\right)^{\circ}$ represents the quantity - $\log$ $\left(f_{\mathrm{H} f \mathrm{Cl}} m_{\mathrm{H}}\right)$ for zero salt concentration. 
The $\mathrm{pH}$ value of the solution may then be obtained from this value by use of a large-scale plot of $-\log \left(f_{\mathrm{H}} m_{\mathrm{H}}\right)^{\circ}$ against - log $\left(f_{\mathrm{H}} f_{\mathrm{C} 1} m_{\mathrm{H}}\right)^{\circ}$ for the same ionic strength, or determined from a more sensitive plot of the differences between - $\log \left(f_{\mathrm{H}} m_{\mathrm{H}}\right)^{\circ}$ and $-\log$ $\left(f_{\mathrm{H}} f_{\mathrm{C} 1} m_{\mathrm{H}}\right)^{\circ}$ against $-\log \left(f_{\mathrm{H}} f_{\mathrm{C} 1} m_{\mathrm{H}}\right)^{\circ}$. A description of the method used in the construction of the latter plot follows. Similar measurements are made with $0.05-m$ hydrochloric acid and $0.05-m$ potassium hydroxide. This alkali is used, since acid potassium phthalate is considered here; for sodium or lithium salts, sodium or lithium hydroxide would be used. From the date of Harned and Ehlers $[19,20]$ and of Harned and Hamer [21], values of 1.4628 and 12.7021 are obtained for $-\log \left(f_{\mathrm{H}} f_{\mathrm{Cl}} m_{\mathrm{H}}\right)^{\circ}$ for hydrochloric acid and potassium hydroxide, respectively. Also by means of the equations

and

$$
-\log \left(f_{\mathrm{H}} m_{\mathrm{H}}\right)=p \mathrm{H}
$$

$$
-\log K_{\mathrm{W}} /\left(f_{\mathrm{OH}} m_{\mathrm{OH}}\right)=-\log \left(f_{\mathrm{H}} m_{\mathrm{H}}\right)=p \mathrm{H}
$$

the $\mathrm{pH}$ values of pure hydrochloric acid (eq 4) and pure potassium hydroxide (eq 5) may be calculated, where $K_{\mathrm{W}}$ is the ionization constant of water and $m$ and $f$ are the molalities and activity coefficients of the ions denoted by subscripts. Values of 1.3817 and 12.6114 are

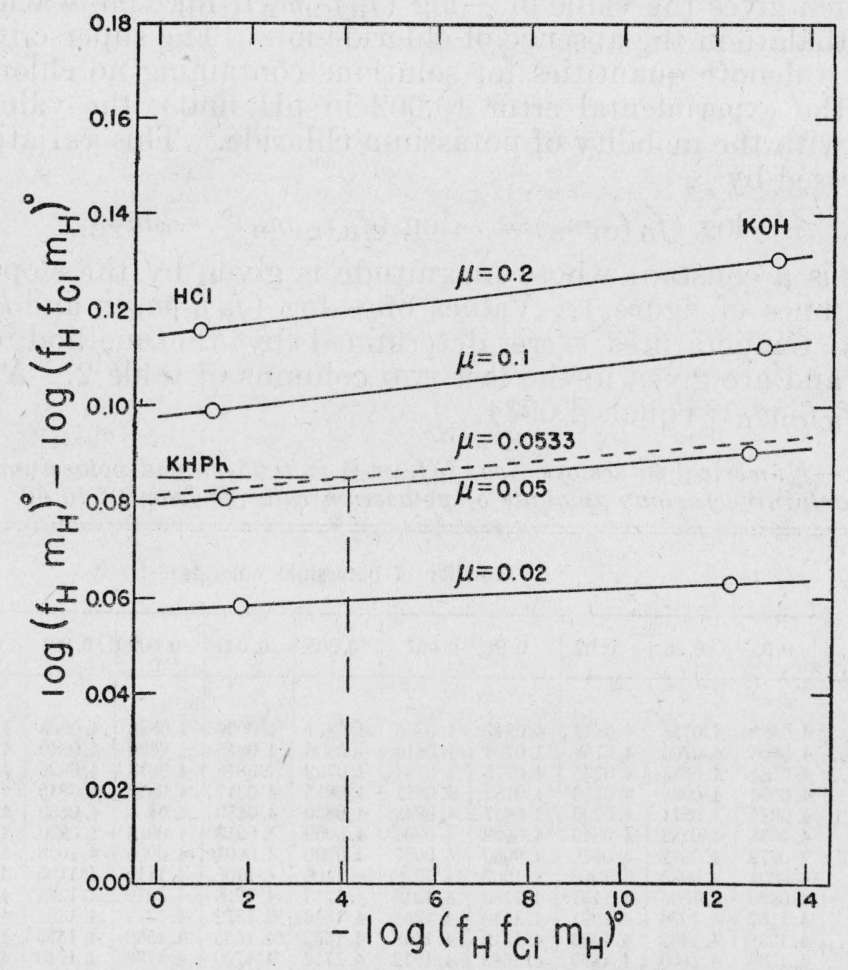

FIGURE 2.-Plots of the differences between - $\left(\log f_{\mathrm{H}} m_{\mathrm{H}}\right)^{\circ}$ and - $\log \left(f_{\mathrm{H}} f_{\mathrm{Cl}} m_{\mathrm{H}}\right)^{\circ}$ against - $\left(\log f_{\mathrm{H}} f_{\mathrm{Cl}} m_{\mathrm{H}}\right)^{\circ}$ at $25^{\circ} C$ for various ionic strengths of hydrochloric acid and potassium hydroxide.

Data for acid potassium phthalate are read from these plots, as shown by the dotted vertical and horizontal lines. 
obtained by these equations for the $\mathrm{pH}$ of $0.05-\mathrm{m}$ solutions of hydrochloric acid and potassium hydroxide, respectively, using 0.8304 for $f_{\mathrm{H}}[19], 1.008 \times 10^{-14}$ for $K_{\mathrm{W}}[21]$, and 0.824 for $f_{\mathrm{OH}}[22,20] .^{4}$ Hence $-\log \left(f_{\mathrm{H}} f_{\mathrm{C} 1} m_{\mathrm{H}}\right)^{\circ}$ and $-\log \left(f_{\mathrm{H}} m_{\mathrm{H}}\right)^{\circ}$ differ by 0.0811 for $0.05-m$ hydrochloric acid and by 0.0907 for $0.05-m$ potassium hydroxide at $25^{\circ} \mathrm{C}$. If the assumption is made that a straight line may be drawn between the points located by plotting these differences against - $\log \left(f_{\mathrm{H}} f_{\mathrm{C} 1} m_{\mathrm{H}}\right)^{\circ}$ for a definite ionic strength, it is then possible to determine the difference between - $\log \left(f_{\mathrm{H}} f_{\mathrm{Cl}} m_{\mathrm{H}}\right)^{\circ}$ and $-\log \left(f_{\mathrm{H}} m_{\mathrm{H}}\right)^{\circ}$ for $0.05-m$ acid potassium phthalate from the plot. ${ }^{5}$

In figure 2 these differences are shown plotted against values of - $\log \left(f_{\mathrm{H}} f_{\mathrm{Cl}} m_{\mathrm{H}}\right)^{\circ}$ for ionic strengths of $0.02,0.05,0.10$, and 0.20 calculated in a similar manner from data in the literature [19 to 22] for $25^{\circ} \mathrm{C}$. From the plot, a difference of 0.0831 is read for $0.05-m$ acid potassium phthalate, for which $-\log \left(f_{\mathrm{H}} f_{\mathrm{C} 1} m_{\mathrm{H}}\right)^{\circ}$ is 4.0934 ; hence its $\mathrm{pH}$ value is $4.0934-0.0831$, or 4.010 at $25^{\circ} \mathrm{C}$.

However, the ionic strength of $0.05-m$ acid potassium phthalate is somewhat larger than 0.05 , owing to several ionic reactions which occur in an aqueous solution of this salt. When acid potassium phthalate is dissolved in water it ionizes according to the equation

$$
\mathrm{KHPh} \rightarrow \mathrm{K}^{+}+\mathrm{HPh}^{-},
$$

and since $\mathrm{HPh}^{-}$behaves as an acid, it ionizes further:

$$
\mathrm{HPh}^{-} \rightleftharpoons \mathrm{H}^{+}+\mathrm{Ph}^{=} \text {, }
$$

to give a certain amount of the bivalent phthalate ion. However, $\mathrm{H}^{+}$does not equal $\mathrm{Ph}^{=}$, since part of the $\mathrm{H}^{+}$ions reacts with $\mathrm{HPh}^{-}$ according to the reaction

$$
\mathrm{H}^{+}+\mathrm{HPh}^{-} \rightleftharpoons \mathrm{H}_{2} \mathrm{Ph},
$$

to give a definite amount of undissociated o-phthalic acid, $\mathrm{H}_{2} \mathrm{Ph}$. The amounts of $\mathrm{H}_{2} \mathrm{Ph}, \mathrm{HPh}^{-}$, and $\mathrm{Ph}^{=}$may be calculated by using the mass action equations for the above reactions and for the two steps in the ionization of $o$-phthalic acid with the aid of the DebyeHückel equations for the activity coefficients. These were found to be, respectively, $0.0032,0.0436$, and 0.0032 , using 0.0013 and 0.0000038 , respectively, [23] for $K_{1}$ and $K_{2}$, the first and second ionization constants of $o$-phthalic acid. Therefore, the ionic strength of a $0.05-m$ solution of acid potassium phthalate is 0.0533 instead $^{6}$ of 0.05 . In figure 2 , the dotted line corresponds to this ionic strength. The posisition of the dotted line was determined from that of the others by means of plots of $\left[\log \left(f_{\mathrm{H}} m_{\mathrm{H}}\right)^{\circ}-\log \left(f_{\mathrm{H}} f_{\mathrm{C}} m_{\mathrm{H}}\right)^{\circ}\right]$ for $\mathrm{pH}$ values of 0 and 14 against the ionic strength. A difference of 0.0854 is then read from this line for acid potassium phthalate, and hence its $\mathrm{pH}$ value is $4.0934-0.0854$, or 4.008 , which is only $0.002 \mathrm{pH}$ unit lower than the value based upon the stoichiometric ionic strength and is the value certified by this Bureau for acid potassium phthalate Standard Sample $84 a$.

\footnotetext{
${ }_{4}^{4}$ The assumption is made that for $f_{\mathrm{OH}}=\sqrt{f_{\mathrm{K}} f_{\mathrm{OH}}}$ for the alkaline solutions and $f_{\mathrm{H}}=\sqrt{f_{\mathrm{H}} f_{\mathrm{Cl}}}$ for the acid solutions, or that the activity coefficient of an ion in an electrolyte is equal to the mean activity coefficient of the ions composing the electrolyte. This does not imply that $f_{\mathrm{H}}=f_{\mathrm{K}}=f_{\mathrm{Cl}}=f_{\mathrm{OH}}$. See E. A. Guggenheim, J. Phys. Chem. 34, $1758(1930)$ for a discussion of this assumption.

5 The small contribution of $m_{\mathrm{H}}$ to the ionic strength can be calculated from the provisional values of $\mathrm{pH}$

6 The ionic strength is equal to $1 / 2 \Sigma_{\mathrm{i}} \mathrm{m}_{\mathrm{i}} \mathrm{i}^{2}$, where $m_{\mathrm{i}}$ and $z_{\mathrm{i}}$ represent the molality and valence of each ionic species. For the above case the ionic strength equals $m_{\mathrm{HPh}}+3 m_{\mathrm{Ph}}+1 / 2 m_{\mathrm{H}}$ or $(0.0436+0.0096+0.00005=$ $0.05325)$.
} 
This method is estimated to be accurate within 0.005 to $0.01 \mathrm{pH}$ unit, even if the stoichiometric ionic strength is employed instead of the true ionic strength. ${ }^{7}$ The $\mathrm{pH}$ values based upon an ionic strength of 0.05 and of 0.0533 are given in columns 3 and 4 of table 3 for the temperatures ${ }^{8} 0^{\circ}$ to $60^{\circ} \mathrm{C}$. Data obtained by former investigators by other methods [1 to 4] are given for comparison. The values obtained in this investigation are 0.04 to 0.05 unit higher than those of Clark and Lubs [1] and Kolthoff and Tekelenburg [2], who used the concentration instead of the activity of hydrogen ions as a basis for their $\mathrm{pH}$ scale, but are in close agreement with the values of Hitchcock and Taylor [3] and of MacInnes, Belcher, and Shedlovsky [4].

TABLE 3. $-p H$ values of $0.05-m$ acid potassium phthalate at temperatures from $0^{\circ}$ to $60^{\circ} \mathrm{C}$, inclusive

[Data of other investigators are given for comparison]

\begin{tabular}{|c|c|c|c|c|c|c|c|}
\hline Temperature & $-\log \left(f_{\mathrm{H}} f_{\mathrm{Cl}} m_{\mathrm{H}}\right)^{\circ}$ & $\begin{array}{l}\mathrm{pH} \text { (based } \\
\text { on an ionic } \\
\text { strenght of } \\
0.05)^{\mathrm{s}}\end{array}$ & $\begin{array}{l}\mathrm{pH} \text { (based } \\
\text { on an ionic } \\
\text { strength of } \\
0.0533) \mathrm{a}\end{array}$ & $\begin{array}{c}\text { Clark and } \\
\text { Lubs } \\
(1916) \\
\\
{[1]}\end{array}$ & $\begin{array}{c}\text { Kolthoff and } \\
\text { Tekelenburg } \\
\text { (1927) } \\
\text { [2] }\end{array}$ & $\begin{array}{c}\text { Hitchcock } \\
\text { and Taylor } \\
(1937-38) \\
{[3]}\end{array}$ & $\begin{array}{c}\text { MacInnes, } \\
\text { Belcher, and } \\
\text { Shedlovsky } \\
\text { (1938) } \\
\text { [4] }\end{array}$ \\
\hline $\begin{array}{c}{ }^{\circ} \mathrm{C} \\
0 \\
5 \\
10 \\
12.5\end{array}$ & $\begin{array}{l}\text { 4. } 0903 \\
\text { 4. } 0851 \\
4.0826\end{array}$ & $\begin{array}{l}\text { 4. } 009 \\
\text { 4. } 004 \\
\text { 4. } 001\end{array}$ & $\begin{array}{r}4.007 \\
4.002 \\
3.999 \\
\text { b } 4.000\end{array}$ & & & & 4.000 \\
\hline 15 & 4.0840 & 4. 002 & 4.000 & & $-\ldots$ & & \\
\hline $\begin{array}{l}18 \\
20 \\
25 \\
30 \\
35\end{array}$ & $\begin{array}{l}\text { 4. } 0875 \\
\text { 4. } 0934 \\
\text { 4. } 1016 \\
\text { 4. } 1122\end{array}$ & $\begin{array}{l}\text { 4. } 005 \\
4.010 \\
\text { 4. } 018 \\
4.027\end{array}$ & $\begin{array}{l}\text { b } 4.001 \\
4.003 \\
4.008 \\
4.016 \\
4.025\end{array}$ & 3.974 & $\begin{array}{c}\text { c } 3.94(3.92) \\
3.96(3.92) \\
\end{array}$ & 4. 008 & 4.000 \\
\hline $\begin{array}{l}38 \\
40 \\
45 \\
50 \\
55\end{array}$ & $\begin{array}{l}\text { 4. } 1237 \\
\text { 4. } 1386 \\
4.1574 \\
4.1741\end{array}$ & $\begin{array}{l}4.038 \\
4.052 \\
4.070 \\
4.086\end{array}$ & $\begin{array}{l}\text { b } 4.032 \\
4.036 \\
4.050 \\
4.068 \\
4.084\end{array}$ & 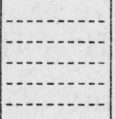 & $\begin{array}{c}3.99(3.93) \\
4.02(3.94) \\
\end{array}$ & 4.025 & $\begin{array}{l}4.015 \\
-. \\
-1\end{array}$ \\
\hline 60 & 4. 1917 & 4. 102 & 4. 101 & & $4.05(3.94)$ & & \\
\hline
\end{tabular}

s $\mathrm{pH}$ values were calculated by the equation $\mathrm{pH}=\frac{-\left(\log f_{\mathrm{H}} f_{\mathrm{Cl}} m_{\mathrm{H}}\right)^{\circ}-P}{Q}$.

b Values calculated by equation 13.

- Values in parentheses were determined with a hydrogen electrode, whereas the other values of Kolthoff and Tekelenburg were determined with a quinhydrone electrode. They considered the hydrogen-electrode values less reliable because of possible reduction of the acid potassium phthalate.

The straight lines of figure 2 may be expressed by the equation

$$
\log \left(f_{\mathrm{H}} m_{\mathrm{H}}\right)^{\circ}-\log \left(f_{\mathrm{H}} f_{\mathrm{Cl}} m_{\mathrm{H}}\right)^{\circ}=a-b \log \left(f_{\mathrm{H}} f_{\mathrm{Cl}} m_{\mathrm{H}}\right)^{\circ},
$$

where $a$ is the value of $\log \left(f_{\mathrm{H}} m_{\mathrm{H}}\right)^{\circ}-\log \left(f_{\mathrm{H}} f_{\mathrm{Cl}} m_{\mathrm{H}}\right)^{\circ}$ for $-\log$ $\left(f_{\mathrm{H}} f_{\mathrm{Cl}} m_{\mathrm{H}}\right)^{\circ}=0$, and $b$ is a constant whose magnitude at various ionic strengths is given by the slopes of the straight lines. This equation may be converted to the form

$$
\mathrm{pH}=\left[-\log \left(f_{\mathrm{H}} f_{\mathrm{Cl}} m_{\mathrm{H}}\right)^{\circ}-P\right] / Q,
$$

\footnotetext{
7 It is difficult at the present time to give an evaluation of the accuracy of this method. Further work on the thermodynamics of mixtures of 0 -phthalic acid and potassium hydroxide (publication pending) will shed light on this subject. However, the close agreement of the $\mathrm{pH}$ value for $0.05-\mathrm{m}$ acid potassium phthalate at $25^{\circ} \mathrm{C}$ obtained by this method with the values obtained by Hitchcock and Taylor and by MacInnes, Belcher, and Shedlovsky given in table 3 indicates that this method is probably accurato within 0.005 to $0.01 \mathrm{pH}$ unit.

${ }_{8}$ Harned and Cook [11] obtained activity coefficients at only $0^{\circ}, 10^{\circ}, 20^{\circ}, 25^{\circ}$, and $35^{\circ} \mathrm{C}$. Values at the other temperatures were obtained by extrapolation.
} 
where $P$ and $Q$ are new constants. Values of $P$ and $Q$ for ionic strengths of 0.05 and 0.0533 are given in table 4 for temperatures from $0^{\circ}$ to $60^{\circ} \mathrm{C}$, inclusive. Values of $P$ and $Q$ for different ionic strengths at $25^{\circ} \mathrm{C}$ are given in table 5. Furthermore, since - $\log \left(f_{\mathrm{H}} f_{\mathrm{Cl}} m_{\mathrm{H}}\right)$ equals $\left(E-E^{\circ}\right) /\left(R T / F^{\prime}\right)+\log m_{\mathrm{Cl}}$, eq 10 may be written

$$
\mathrm{pH}=\left[\left(E-E^{\circ}\right) /(R T / F)+\log ^{\circ} m_{\mathrm{Cl}}-P\right] / Q,
$$

by which the $\mathrm{pH}$ may be calculated directly from the emf and the numerical values of $P$ and $Q$ given in table 4 , remembering that $P$ and $Q$ depend upon the ionic strength and are for solutions containing no chloride ion. For solutions containing $\mathrm{Cl}^{-}$ions, different values of $P$ and $Q$ must be used, which are given in table 6 .

TABLE 4.-Numerical values of the constants $P$ and $Q$ of equation 10 for ionic strengths of 0.05 and 0.0533

\begin{tabular}{|c|c|c|c|c|}
\hline \multirow{2}{*}{$\begin{array}{l}\text { Temper- } \\
\text { ature }\end{array}$} & \multicolumn{4}{|c|}{ Ionic strength } \\
\hline & \multicolumn{2}{|c|}{0.05} & \multicolumn{2}{|c|}{0.0533} \\
\hline $\begin{array}{r}{ }^{\circ} C \\
\quad 0 \\
4 \quad 5 \\
10 \\
1 \quad 15 \\
120\end{array}$ & $\begin{array}{c}P \\
0.0772 \\
.0773 \\
.0776 \\
.0782 \\
.0789\end{array}$ & $\begin{array}{c}Q \\
1.00107 \\
1.00102 \\
1.00096 \\
1.00094 \\
1.00090\end{array}$ & $\begin{array}{c}P \\
0.0787 \\
.0789 \\
.0795 \\
.0799 \\
.0805\end{array}$ & $\begin{array}{r}Q / v \mid \\
1.00112 \\
1.00106 \\
1.00101 \\
1.00098 \\
1.00094\end{array}$ \\
\hline $\begin{array}{l}25 \\
30 \\
35 \\
40 \\
45\end{array}$ & $\begin{array}{l}.0796 \\
.0807 \\
.0818 \\
.0829 \\
.0838\end{array}$ & $\begin{array}{l}1.00085 \\
1.00082 \\
1.00079 \\
1.00076 \\
1.00073\end{array}$ & $\begin{array}{l}.0814 \\
.0824 \\
.0835 \\
.0847 \\
.0856\end{array}$ & $\begin{array}{l}1.00089 \\
1.00086 \\
1.00083 \\
1.00080 \\
1.00076\end{array}$ \\
\hline $\begin{array}{l}50 \\
55 \\
60\end{array}$ & $\begin{array}{l}.0849 \\
.0859 \\
.0869\end{array}$ & $\begin{array}{l}1.00068 \\
1.00066 \\
1.00065\end{array}$ & $\begin{array}{l}.0867 \\
.0877 \\
.0888\end{array}$ & $\begin{array}{l}1.00072 \\
1.00070 \\
1.00067\end{array}$ \\
\hline
\end{tabular}

TABLE 5.-Numerical values of the constants $P$ and $Q$ of equation 10 for different ionic strengths at $25^{\circ} \mathrm{C}$

\begin{tabular}{|c|c|c|}
\hline $\begin{array}{c}\text { Ionic } \\
\text { strength }\end{array}$ & $P$ & $Q$ \\
\hline 0.005 & 0.0313 & 1.00040 \\
.01 & .0423 & 1.00055 \\
.02 & .0575 & 1.00068 \\
.05 & .0796 & 1.00085 \\
.10 & .0976 & 1.00092 \\
.20 & .1146 & 1.00096 \\
\hline
\end{tabular}

The $\mathrm{pH}$ values of the solutions of $0.05-m$ acid potassium phthalate containing various amounts of potassium chloride were calculated similarly, using the proper values of $P$ and $Q$. The value are given in table 7 , and in figure 3 are shown plotted against the molality of potassium chloride for temperatures of $0^{\circ}, 25^{\circ}, 45^{\circ}$, and $60^{\circ} \mathrm{C}$. The plots exhibit a slight curvature, appearing at molalities between 0.03 and 0.04 . The variation of $\mathrm{pH}$ with salt concentration may be expressed at all the temperatures by the equation

$$
\mathrm{pH}_{\text {with sa It }}=\mathrm{pH}_{\text {wlthout sa lt }}-0.993 m_{\mathrm{KCl}}+2.124 m_{\mathrm{KCl}}^{2} \text {. }
$$


In figure 4 the $\mathrm{pH}$ of $0.05-\mathrm{m}$ acid potassium phthalate (curve A) and of $0.05-m$ acid potassium phthalate containing $0.02-m$ potassium chloride (curve B) and 0.05- $m$ potassium chloride (curve $\mathrm{C}$ ) are shown plotted against the temperature in degrees centigrade. The curves

TABLE 6.-Numerical values of constants $P$ and $Q$ for various concentrations of potassium chloride in $0.05-m$ acid potassium phthalate for use in equation 10

\begin{tabular}{|c|c|c|c|c|c|c|c|c|c|}
\hline \multirow{3}{*}{$\begin{array}{l}\text { Tempera- } \\
\text { ture }\end{array}$} & \multicolumn{9}{|c|}{ Molality of potassium chloride } \\
\hline & 0.001 & 0.002 & 0.003 & 0.005 & 0.007 & 0.01 & 0.02 & 0.03 & 0.05 \\
\hline & \multicolumn{9}{|c|}{$P$ VALUES } \\
\hline \multicolumn{10}{|l|}{${ }^{\circ} \mathrm{C}$} \\
\hline $\begin{array}{r}0 \\
5 \\
10 \\
15 \\
20\end{array}$ & $\begin{array}{r}0.0783 \\
.0791 \\
.0799 \\
.0807 \\
.0810\end{array}$ & $\begin{array}{r}0.0788 \\
.0796 \\
.0804 \\
.0813 \\
.0821\end{array}$ & $\begin{array}{r}0.0794 \\
.0804 \\
.0810 \\
.0819 \\
.0827\end{array}$ & $\begin{array}{r}0.0805 \\
.0814 \\
.0822 \\
.0829 \\
.0839\end{array}$ & $\begin{array}{r}0.0811 \\
.0820 \\
.0829 \\
.0837 \\
.0845\end{array}$ & $\begin{array}{r}0.0830 \\
.0838 \\
.0847 \\
.0856 \\
.0864\end{array}$ & $\begin{array}{r}0.0872 \\
.0880 \\
.0890 \\
.0899 \\
.0909\end{array}$ & $\begin{array}{r}0.0916 \\
.0926 \\
.0936 \\
.0946 \\
.0956\end{array}$ & $\begin{array}{r}0.0980 \\
.0988 \\
.0999 \\
.1009 \\
.1010\end{array}$ \\
\hline $\begin{array}{l}25 \\
30 \\
35 \\
40 \\
45\end{array}$ & $\begin{array}{l}.0824 \\
.0833 \\
.0842 \\
.0851 \\
.0861\end{array}$ & $\begin{array}{l}.0830 \\
.0836 \\
.0847 \\
.0857 \\
.0867\end{array}$ & $\begin{array}{l}.0836 \\
.0841 \\
.0853 \\
.0864 \\
.0873\end{array}$ & $\begin{array}{l}.0848 \\
.0857 \\
.0866 \\
.0875 \\
.0885\end{array}$ & $\begin{array}{l}.0855 \\
.0865 \\
.0874 \\
.0883 \\
.0894\end{array}$ & $\begin{array}{l}.0874 \\
.0883 \\
.0892 \\
.0903 \\
.0913\end{array}$ & $\begin{array}{l}.0919 \\
.0928 \\
.0938 \\
.0948 \\
.0959\end{array}$ & $\begin{array}{l}.0965 \\
.0975 \\
.0985 \\
.0996 \\
.1008\end{array}$ & $\begin{array}{l}.1029 \\
.1042 \\
.1052 \\
.1065 \\
.1076\end{array}$ \\
\hline $\begin{array}{l}50 \\
55 \\
60\end{array}$ & $\begin{array}{l}.0871 \\
.0881 \\
.0891\end{array}$ & $\begin{array}{l}.0877 \\
.0887 \\
.0898\end{array}$ & $\begin{array}{l}.0884 \\
.0894 \\
.0904\end{array}$ & $\begin{array}{l}.0896 \\
.0906 \\
.0917\end{array}$ & $\begin{array}{l}.0904 \\
.0915 \\
.0926\end{array}$ & $\begin{array}{l}.0924 \\
.0935 \\
.0946\end{array}$ & $\begin{array}{l}.0971 \\
.0981 \\
.0994\end{array}$ & $\begin{array}{l}.1020 \\
.1032 \\
.1044\end{array}$ & $\begin{array}{l}.1090 \\
.1101 \\
.1114\end{array}$ \\
\hline & \multicolumn{9}{|c|}{$Q$ VALUES } \\
\hline & 1.00111 & 1.00110 & 1. 00110 & 1. 00109 & 1. 00109 & 1.00108 & 1. 00103 & 1.00097 & 1. 00089 \\
\hline 5 & 1.00105 & 1. 00104 & 1. 00104 & 1. 00103 & 1. 00103 & 1. 00102 & 1. 00097 & 1. 00091 & $\begin{array}{l}1.00082 \\
\text { 1. }\end{array}$ \\
\hline 10 & 1. 00100 & 1. 00099 & 1. 00099 & 1. 00097 & 1. 00097 & 1. 00096 & 1. 00091 & 1. 00084 & 1. 00075 \\
\hline 15 & 1. 00097 & 1.00096 & 1. 00096 & 1. 00094 & 1. 00093 & 1. 00091 & 1. 00085 & 1. 00078 & 1.00068 \\
\hline 20 & 1.00093 & 1. 00092 & 1. 00092 & 1.00090 & 1.00089 & 1.00087 & 1. 00081 & 1.00073 & 1. 00063 \\
\hline 25 & 1. 00088 & 1. 00087 & 1. 00087 & 1. 00084 & 1. 00084 & 1. 00082 & 1. 00076 & 1. 00068 & 1. 00058 \\
\hline & 1. 00085 & 1. 00084 & 1. 00084 & 1. 00082 & 1.00081 & 1.00079 & 1. 00073 & 1.00065 & 1. 00055 \\
\hline 35 & 1. 00082 & 1. 00081 & 1. 00081 & 1. 00079 & 1. 00078 & 1.00076 & 1. 00070 & 1. 00062 & 1. 00052 \\
\hline 40 & 1.00079 & 1.00078 & 1. 00078 & 1. 00076 & 1. 00075 & 1.00073 & 1. 00067 & 1.00059 & 1.00045 \\
\hline 45 & 1.00075 & 1.00074 & 1. 00073 & 1.00071 & 1. 00069 & 1.00067 & 1. 00061 & 1. 00053 & 1. 00043 \\
\hline 50 & 1.00071 & 1.00069 & 1. 00068 & 1. 00066 & 1.00064 & 1.00062 & 1.00055 & 1. 00046 & 1. 00035 \\
\hline 55 & 1.00069 & 1. 00067 & 1. 00066 & 1. 00064 & 1. 00062 & 1. 00060 & 1. 00053 & 1. 00044 & 1. 00033 \\
\hline 60 & 1. 00066 & 1. 00064 & 1. 00063 & 1. 00061 & 1. 00059 & 1. 00057 & 1. 00050 & 1. 00041 & 1. 00030 \\
\hline
\end{tabular}

TABLE 7.- $\mathrm{pH}$ values of $0.05-m$ acid potassium phthalate containing various amounts of potassium chloride at temperatures from $0^{\circ}$ to $60^{\circ} \mathrm{C}$, inclusive

\begin{tabular}{|c|c|c|c|c|c|c|c|c|c|}
\hline \multirow{2}{*}{$\begin{array}{l}\text { Tempera- } \\
\text { ture }\end{array}$} & \multicolumn{9}{|c|}{ Molality of potassium chloride } \\
\hline & 0.001 & 0.002 & 0.003 & 0.005 & 0.007 & 0.01 & 0.02 & 0.03 & 0.05 \\
\hline $\begin{array}{l}{ }^{\circ} \mathrm{C} \\
0 \\
5 \\
10 \\
15 \\
20 \\
\end{array}$ & $\begin{array}{l}4.008 \\
4.001 \\
3.999 \\
4.000 \\
4.003\end{array}$ & $\begin{array}{l}4.006 \\
\text { 3. } 999 \\
3.997 \\
3.997 \\
4.000\end{array}$ & $\begin{array}{l}4.007 \\
4.000 \\
3.997 \\
3.996 \\
3.999\end{array}$ & $\begin{array}{l}4.002 \\
3.998 \\
3.993 \\
3.995 \\
3.998\end{array}$ & $\begin{array}{l}4.001 \\
3.996 \\
3.993 \\
3.994 \\
3.997\end{array}$ & $\begin{array}{l}\text { 3. } 997 \\
3.992 \\
3.989 \\
3.989 \\
3.993\end{array}$ & $\begin{array}{l}\text { 3. } 990 \\
\text { 3. } 985 \\
\text { 3. } 981 \\
\text { 3. } 982 \\
\text { 3. } 985\end{array}$ & $\begin{array}{l}3.980 \\
3.974 \\
3.971 \\
3.972 \\
3.975\end{array}$ & $\begin{array}{l}3.965 \\
3.959 \\
3.955 \\
3.956 \\
3.960\end{array}$ \\
\hline $\begin{array}{l}25 \ldots \\
30 \ldots \\
35 \ldots \\
40 \ldots \\
45\end{array}$ & $\begin{array}{l}4.007 \\
4.016 \\
4.025 \\
4.036 \\
4.049\end{array}$ & $\begin{array}{l}4.005 \\
4.012 \\
4.023 \\
4.033 \\
4.048\end{array}$ & $\begin{array}{l}4.004 \\
4.012 \\
4.022 \\
4.032 \\
4.047\end{array}$ & $\begin{array}{l}4.003 \\
4.010 \\
4.020 \\
4.031 \\
4.045\end{array}$ & $\begin{array}{l}4.002 \\
4.009 \\
4.019 \\
4.030 \\
4.043\end{array}$ & $\begin{array}{l}\text { 4. } 000 \\
\text { 4. } 005 \\
\text { 4. } 014 \\
4.025 \\
4.040\end{array}$ & $\begin{array}{l}\text { 3. } 989 \\
\text { 3. } 997 \\
4.006 \\
4.018 \\
4.031\end{array}$ & $\begin{array}{l}\text { 3. } 979 \\
\text { 3. } 987 \\
3.997 \\
4.008 \\
4.021\end{array}$ & $\begin{array}{l}\text { 3. } 964 \\
3.971 \\
3.982 \\
3.992 \\
4.008\end{array}$ \\
\hline $\begin{array}{l}50 \\
55 \\
60\end{array}$ & $\begin{array}{r}4.068 \\
4.083 \\
4.099\end{array}$ & $\begin{array}{l}4.066 \\
4.082 \\
4.099\end{array}$ & $\begin{array}{l}4.064 \\
4.080 \\
4.097\end{array}$ & $\begin{array}{l}\text { 4. } 063 \\
4.079 \\
4.095\end{array}$ & $\begin{array}{l}4.062 \\
4.077 \\
4.095\end{array}$ & $\begin{array}{l}4.057 \\
4.073 \\
4.091\end{array}$ & $\begin{array}{l}\text { 4. } 049 \\
\text { 4. } 066 \\
\text { 4. } 082\end{array}$ & $\begin{array}{l}4.039 \\
4.055 \\
4.072\end{array}$ & $\begin{array}{l}4.024 \\
4.040 \\
4.058\end{array}$ \\
\hline
\end{tabular}


are displaced a constant amount at all temperatures by the addition of potassium chloride and exhibit a minimum at about $10^{\circ} \mathrm{C}$. The variation of the $\mathrm{pH}$ of a $0.05-m$ solution of acid potassium phthalate containing no potassium chloride may be represented by the equation

$$
\mathrm{pH}=5.13 \log T+1519.62 / T+0.01092 T-17.039
$$

where $T=t^{\circ} \mathrm{C}+273.16$. For the solutions containing salt, the equation is modified by changing 17.039 by an amount determined by eq 12. The $\mathrm{pH}$ values are constant within $0.005 \mathrm{pH}$ unit between $0^{\circ}$ and $30^{\circ} \mathrm{C}$, and this fact increases their usefulness as $\mathrm{pH}$ standards.

The potentiometric method herein described is a gereral one, in that it may be used equally well for other concentrations and other buffer solutions for the temperature range of $0^{\circ}$ to $60^{\circ} \mathrm{C}$. It has the advantage of being less involved, although less precise, than ones based upon a complete thermodynamic study of the system, and the $\mathrm{pH}$ value of a solution may be determined directly from the electromotive force of galvanic cells without liquid junction.

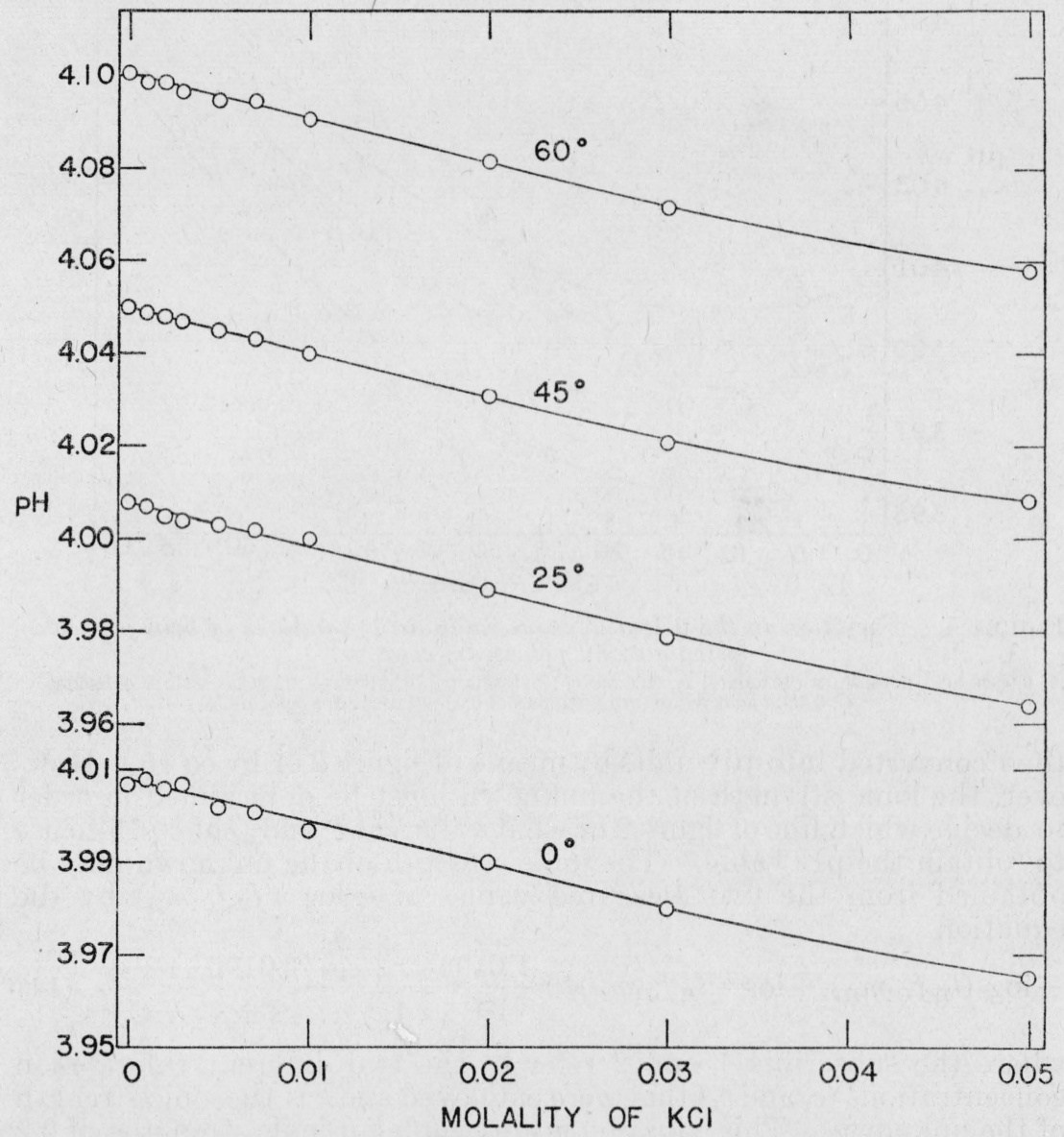

FIGURE 3.-Variation in the $\mathrm{pH}$ of 0.05-m acid potassium phthalate with the molality of added potassium chloride at $0^{\circ}, 25^{\circ}, 45^{\circ}$, and $60^{\circ} \mathrm{C}$. 
The method may also be used to determine approximately the $\mathrm{pH}$ values and ionic strengths of unknowns [24] of low salt content, but if chloride salts are present, the chloride concen tration must be determined for use in the equations. The computations are simpler if the unknown contains no chloride. First, two different amounts of potassium chloride are added to two separate portions of the unknown, and $-\log \left(f_{\mathrm{H}} f_{\mathrm{Cl}} m_{\mathrm{H}}\right)$ is calculated by eq 2 for each portion from the electromotive force and the known chloride-ion concentration. The value of $-\log \left(f_{\mathrm{H}} f_{\mathrm{C} 1} m_{\mathrm{H}}\right)^{\circ}$ for the solution without added chloride is then obtained by means of a straight-line plot of the values of - log $\left(f_{\mathrm{H}} f_{\mathrm{C} 1} m_{\mathrm{H}}\right)$ against the chloride-ion concentration. This value is

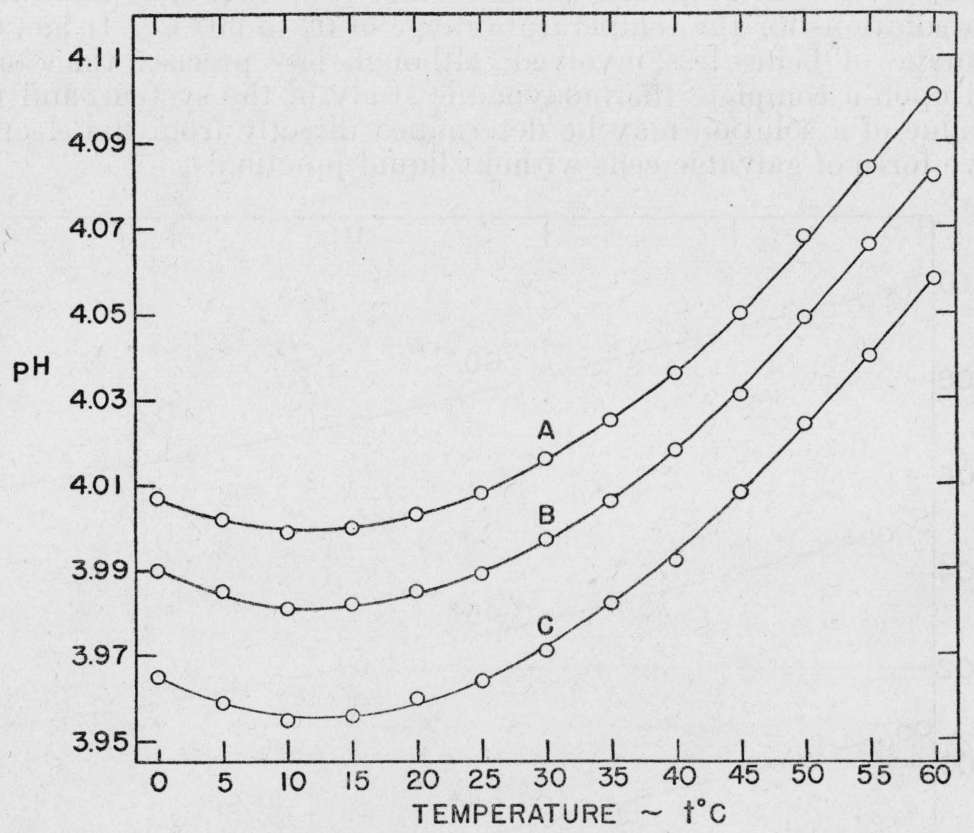

FIGURE 4.-Variation in the $\mathrm{pH}$ of aqueous solutions of mixtures of acid potassium phthalate and potassium chloride.

$A, 0.05-m$ acid potassium phthalate; $B, 0.05-m$ acid potassium phthalate $+0.02-m$ potassium chloride; $C, 0.05-m$ acid potassium phthalate $+0.05-m$ potassium chloride.

then converted into $\mathrm{pH}$ units by means of figure 2 or by eq 10 . However, the ionic strength of the unknown must be determined in order to decide which line of figure 2 or what values of $P$ and $Q$ of eq 10 to use to obtain the $\mathrm{pH}$ value. The ionic strength of the unknown may be obtained from the two measured values of $-\log \left(f_{\mathrm{H}} f_{\mathrm{C} 1} m_{\mathrm{H}}\right)$ by the equation

$$
-\log \left(f_{\mathrm{H}} f_{\mathrm{C} 1} m_{\mathrm{H}}\right)_{1}+\log \left(f_{\mathrm{H}} f_{\mathrm{Cl}} m_{\mathrm{H}}\right)_{2}=\frac{1.0196 \sqrt{x+c_{1}}}{1+\sqrt{x+c_{1}}}-\frac{1.0196 \sqrt{x+c_{2}}}{1+\sqrt{x+c_{2}}}
$$

where the subscripts 1 and 2 refer to the two different chloride-ion concentrations $\left(c_{1}\right.$ and $\left.c_{2}\right)$ that were employed and $x$ is the ionic strength of the unknown. This equation is applicable for ionic strengths of 0.2 or less. An illustration of the method follows.

An unknown solution ${ }^{9}$ upon the addition of $0.01-m$ and $0.02-m$

\footnotetext{
This solution contained 0.01 mole of acid potassium phthalate and 0.01 mole of dipotassium phthalate per $1,000 \mathrm{~g}$ of water.
} 
potassium chloride gave, respectively, electromotive forces of $0.65431 \mathrm{v}$ and $0.63472 \mathrm{v}$. These give, respectively, 5.3035 and 5.2743 for $-\log$ $\left(f_{\mathrm{H}} f_{\mathrm{C}} m_{\mathrm{H}}\right)$. The difference $(0.02922)$ of the two values added to the first value gives 5.3327 for $-\log \left(f_{\mathrm{H}} f_{\mathrm{Cl}} m_{\mathrm{H}}\right)^{\circ}$ for the unknown solution containing no chloride ion. The same difference substituted in eq 14 gives 0.0037 for $x$, the ionic strength of the unknown. From interpolation of the data of table $4, P$ and $Q$ are, respectively, 0.0200 and 1.00025. Therefore, by means of eq 10 the $\mathrm{pH}$ of the unknown is $(5.3327-0.0200) / 1.00025=5.311$. This solution was known to have an ionic strength of 0.004 and a $\mathrm{pH}$ of 5.326 , which agree adequately with the calculated values.

Similar applications to other unknowns may not be as successful. However, the method may be employed with a precision of about 0.1 or better in $\mathrm{pH}$ for solutions of ionic strength less than 0.2 . The values of $P$ given in table 5 correspond to the errors in $\mathrm{pH}$ at different ionic strengths if no corrections were made for the ionic strength. For example, in the above illustration the error in the $\mathrm{pH}$ of the unknown solution would be 0.02 if no corrections had been made for the ionic strength. Furthermore, the method cannot be applied successfully to a chloride solution unless its concentration is known because the emf is a function of the activity of the chloride ion. Additional studies of effects of polar and nonpolar salts of high concentrations on the $\mathrm{pH}$ of solutions should make possible an extension of the method and theory to a wider range of ionic strengths.

\section{REFERENCES}

[1] W. M. Clark and H. A. Lubs, J. Bio. Chem. 25, 479 (1916).

[2] I. M. Kolthoff and F. Tekelenburg, Rec. trav. chim. 46, 33 (1927).

[3] D. I. Hitchcock and A. C. Taylor, J. Am. Chem. Soc. 59, 1812 (1937).

[4] D. A. MacInnes, D. Belcher, and T. Shedlovsky, J. Am. Chem. Soc. 60, 1094 (1938).

[5] W. J. Hamer and S. F. Acree (publication pending).

[6] B. Wingfield and S. F. Acree, J. Research NBS 19, 163 (1937) RP1018; J. Am. Leather Chem. Assn. 31, 403 (1936).

[7] B. Wingfield, W. H. Goss, W. J. Hamer, and S. F. Acree, ASTM Bul. 90, 15 (1938).

[8] W. J. Hamer, Trans. Electrochem. Soc. 71, 45 (1937).

[9] C. N. Murray and S. F. Acree, BS J. Research 7, 713 (1931) RP369.

[10] G. M. Kline, M. R. Meacham, and S. F. Acree, BS J. Research 8, 101 (1932) RP403.

[11] W. J. Hamer and S. F. Acree, J. Research NBS 17, 605 (1936) RP930.

[12] R. G. Bates, W. J. Hamer, G. G. Manov, and S. F. Acree, J. Research NBS 29, 183 (1942) RP1495.

[13] W. J. Hamer and S. F. Acree, J. Research NBS 23, 647 (1939) RP1261.

[14] W. J. Hamer, J. O. Burton, and S. F. Acree, J. Research NBS 24, 260 (1940).

[15] W. J. Hamer, G. D. Pinching, and S. F. Acree, J. Research NBS 31, 291 (1943) RP1567.

[16] J. O. Burton, W. J. Hamer, and S. F. Acree, J. Research NBS 16, 575 (1936) RP895.

[17] N. E. Loomis and S. F. Acree, Chem. J. 46, 621 (1911).

[18] N. Bronsted, J. Am. Chem. Soc. 45, 2898 (1923).

[19] H. S. Harned and R. W. Ehlers, J. Am. Chem. Soc. 55, 2179 (1933).

[20] H. S. Harned, J. Am. Chem. Soc. 5\%, 1865 (1935).

[21] H. S. Harned and W. J. Hamer, J. Am. Chem. Soc. 55, 2194, 4496 (1933).

[22] H. S. Harned and M. A. Cook, J. Am. Chem. Soc. 59, 496, 1890 (1937).

[23] S. Glasstone. Introduction to Electrochemistry, p. 330 (D. Van Nostrand Co., Inc., New York, N. Y., 1942).

[24] R. G. Bates and S. F. Acree, J. Research NBS 32, 131 (1944) RP1580.

Washington, January 27, 1944. 